\title{
International Best Practices, Domestic Constraints and International Listing: Evidence from China's State Banking Sector*
}

\section{Damian Tobin}

Department of Finance \& Management Studies (DeFiMS), School of Oriental \& African Studies (SOAS), University of London

\section{Shikha Singh}

Deloitte Touche Tohmatsu, Hong Kong

Address for Correspondence: Dr. Damian Tobin, CeFiMS, SOAS, University of London, Thornhaugh Street, Russell Square, London WC1H 0XG, United Kingdom. Phone: +44 207898 48058. Fax: +44 207898 4089. Email: dt29@soas.ac.uk.

\begin{abstract}
The objective of this paper is to gauge the extent to which Chinese state-owned commercial banks are converging with international best banking and corporate governance practices, with a particular focus on the policy of international listing given its recent popularity. Drawing on the international listings of China's stateowned banks on the Hong Kong stock market, the paper finds that formal convergence is possible to achieve. More difficult to achieve is substantive convergence. In general the findings suggest that the domestic institutional framework still matters, but what may matter more is that banks have the autonomy to integrate best-practices in a manner consistent with domestic conditions.
\end{abstract}

Key Words: Corporate Governance, Banks, China, Hong Kong, International Listing JEL: G21; G38, O16; O19, P31.

Word Count: 10,680 (including notes, references, figures and tables)

\footnotetext{
* The authors would like to thank Pauline Loong, Leo F. Goodstadt, Stuart Chiron, Ashley Alder, David Li, Mathew Yiu, Roger Luk, Simon Ogus, and Steven Green for their assistance with various aspects of the research fieldwork and Laixiang Sun, Christopher Howe and Sanzhu Zhu for helpful suggestions.
} 


\section{Introduction}

The importance of good corporate governance in banks is well-known (e.g. Levine, 2003, Arun \& Turner, 2004). The importance attached by China to establishing a formal institutional structure for better corporate governance in state-owned commercial banks, is therefore part of a wider system of good governance required for efficient economic performance, even within a modern communist state. The objective in improving governance should be to enable banks to make decisions solely based on commercial consideration without the interference of political interests (Hope \& Hu, 2006). The corporate governance literature suggests successful reform is dependent on the legal protection of shareholders (La Porta et al, 2000), a functioning prudential regulatory system (Arun \& Turner, 2004), and various levels of foreign competition (Arun \& Turner, 2004; Hope \& Hu, 2006). Therefore attempts by many developing economies to develop better corporate governance practices are likely to be constrained by weak domestic institutions, even if they operate or have listings in more advanced economies with higher levels of legal protections (e.g. Black, 2001). This is particularly relevant for China, where large state-owned commercial banks have implicitly used international listing on Hong Kong's stock market as a mechanism to integrate international best-practices. An interesting question therefore concerns whether developing economies like China can lever on the institutions of more developed economies to develop better corporate governance practices, even in the absence of domestic institutional convergence?

The objective of this paper is to gauge the extent to which Chinese state-owned commercial banks are converging with international best banking and corporate practices, with a particular focus on the policy of international listing given its recent popularity. Using the OECD Corporate Governance Principles and Basel Core Principles as benchmarks of best practice, the focus of the paper is on whether in the absence of full domestic convergence, banks could use Hong Kong's institutional framework as a means of converging with international best practice. Generally the paper finds evidence that international listing has brought large state banks much closer to international practices. Focusing on the case of the Bank of China Hong Kong (BOCHK), a Chinese state-owned bank with a long history of international exposure, the paper suggests that formal convergence is indeed possible, but that substantive convergence is much more difficult to achieve. Formal convergence refers to regulatory compliance while substantive convergence depends much more on the integrity of 
directors and their supervisors. The case of the BOCHK illustrates that although it operated in a comparatively advanced banking sector, its corporate governance practices, management and size were often more comparable to mainland state banks. This implies that ultimately the domestic governance framework matters (Black, 2001), but that international listing can act as a catalyst for inducing better corporate governance over time. In this sense, what may matter more is that China's banks integrate best practises in a manner that is consistent with domestic institutions.

The following sections examine whether restructuring and international listing have brought China's state banks closer to international best-standards using the OECD Principles of Corporate Governance and the Basel Committee Core Principles as benchmarks of best practice. Section two outlines the analytical framework focusing on the extent to which international listing can bring banks closer to best practice. It outlines the background to the international listings of China's banks generally. Section three focuses more specifically the case of BOCHK. This includes an analysis of the corporate governance framework, minority shareholder interests, the Shanghai loan scandal, disclosure and transparency, prudential regulation and the board of directors. Section four discusses the extent to which formal and substantive convergence has been achieved. Section five concludes.

\section{Analytical benchmarks and international listing}

A discussion of governance practices cannot take place in terms of absolutes. There is no single, unified system of governance that is expected, accepted and implemented worldwide. In fact recent research has confirmed the existence of a wide variety of ownership and control structures (Hansman, 1996; Sun, 2003). Governance practices differ across markets and while there is a general consensus that some practices are better than others, variation occurs even amongst jurisdictions that are seen to be following similar practices. Given this variation, there is extensive discussion as to how markets across the world are interacting. In accordance with this view, the OECD has issued a set of Corporate Governance Principles, which are viewed as recommendations of best practice to enterprises and governments of all countries regarding governance practices. Similarly, in the wake of the increasing global nature of the world's banking system and the threats of international financial instability, the Basel Committee on banking supervision has drawn up core principles of international best banking practices. In order to look at the corporate governance practices adopted by 
newly internationally listed Chinese banks in a more structured manner, we adopt a two-stage analytical approach using both the OECD's Principles and the more sector specific governance requirements of the Basel banking framework. Taken together these frameworks provided a comprehensive benchmark of international best-practices.

\subsection{Analytical benchmarks}

Drawing on the approach of Madera \& Sun (2005) we first use the OECD principles as an analytical prism. The Principles, the latest version of which came in 2004, comprise of six basic principles of corporate governance, and provide a basic standard against which practices of listed companies can be benchmarked. The six principles call upon a company to ensure the following:

(1) A basis for an effective corporate governance framework;

(2) the rights of shareholders;

(3) the equitable treatment of shareholders;

(4) the role of stakeholders in corporate governance;

(5) suitable levels of disclosure and transparency and

(6) the fulfilment of responsibility by the board of directors

What is important to understand about the OECD principles is that they represent a compromise between member countries on what constitutes best practices. Different countries will undoubtedly attach different levels of importance to different principles. In our analysis the major emphasis will be on establishing whether an effective framework exists; whether a Hong Kong listing can better protect minority shareholders and other stakeholders; whether listing can induce a higher level of transparency; and, whether it makes the directors more accountable for their actions?

Secondly, we look at the Basel Committee core principles on banking supervision, specifically those relating to corporate governance. The Basel Committee comprises of senior representatives from central banks and supervisory authorities in developed economies including the UK, US, France, Germany and Switzerland. The Basel committee has a long history of promoting the objective of better banking supervision through improved transparency and effective market discipline. This commitment is reflected in the committees Core Principles for Effective Banking Supervision (The Basel Core Principles) originally published in 1997 and revised in 2006. These comprise of 25 principles, which can be broadly categorised into seven groups: Objectives (including independence, transparency and cooperation); licensing and structure; prudential regulation; ongoing supervision; accounting and disclosure; 
powers of supervisors; and cross-border supervision (Table 1). Since the Core Principles represent a complex set of compliance demands on banks and whose full assessment is beyond the scope of this paper, our purpose is to examine the extent to which China's banks are achieving compliance with the general spirit of the principles. We focus on the areas of most relevance to the Mainland banking sector including transparency, prudential regulation, risk-management practices, remedial action and cross-border enforcement.

(Insert Table 1 here)

\subsection{International listing and China's banking sector}

Given the severe problems facing China's banking sector, a key question concerned how to integrate better corporate governance practices? Feinerman (2007) argues that there must be an incentive to change, be it access to cheaper capital or reduced interference from government or political agencies. Chinese banks that list in Hong Kong are required to abide by the Hong Kong Listing Rules. However, Hong Kong's Corporate Governance Code is based on the "comply or explain” principle typically associated with the UK, and carries no requirement of conformity. Therefore although listing may achieve some formal improvements, the essence of good corporate governance goes beyond mere regulatory compliance. It concerns doing the right thing not because the rules or law says so or because someone is watching, but because it is right (Feinerman, 2007). Such substantive commitments to good governance practices are better measured against the OECD principles and international best-banking practices.

As a major listing destination, the Hong Kong stock exchange (HKSE) provides an ideal environment for Chinese firms hoping to attain higher standards of governance. Hong Kong has one of the highest standards of corporate governance in Asia, second only to Singapore (CLSA, 2004). In terms of transparency, Hong Kong typically ranks alongside such countries as the United States and Britain in terms of business peoples perceptions of corruption. ${ }^{1}$ The HKSE requires companies to undergo extensive auditing by independent international auditors before listing. The consequence of the above is that the act of listing in Hong Kong achieves an almost mechanical compliance with the first OECD principle of governance. 
The reasons for the popularity of Hong Kong as a listing destination among Chinese state-enterprises stem from the proximity of the territory to the mainland, geographically, linguistically and culturally. Schenk (2007) points out the long history of financial relations between Hong Kong and the Mainland. These relations predated the foundation of the PRC and survived the nationalization of China's financial system during the 1950s. More general reasons cited for international listings include greater access to international capital, greater international visibility and improving stock liquidity. Pagano et al (2002) find that firms from countries with weaker shareholder protection are more eager in seeking foreign listings. From 1993 onward some 100 Chinese enterprises (mainly sate-owned, i.e., SOEs) have listed foreign or H-shares on the HKSE. A further 52 subsidiaries of Chinese enterprises (mainly SOEs) have incorporated in Hong Kong and been listed as “red chips” (Table 2).

(Insert Table 2 here)

However, it needs to be noted that these exists a gap between formal compliance with listing requirements and real or substantial improvements in corporate governance. Even in Hong Kong there exists a wide variety of governance practices among listed companies. The CLSA (2004) survey illustrated a firm level variation of over 23 percentage points between the upper and lower quartile scores of listed Hong Kong companies. Part of this variation can be explained by the fact that the HKSE is not a prudential regulator. Both the HKSE and the Hong Kong Securities and Futures Commission (HKSFC) rely to a large extent on the integrity of the due-diligence process. $^{2}$ While the due-diligence process makes it much more difficult to hide offbalance sheet commitments, it does not guarantee good corporate practices ex-post. Black (2001) argues that although firms can escape weak domestic governance systems through international listing, such escape may be only partial if local enforcement and institutions remain weak. The implication being that to be fully effective, improvements in corporate governance must be diffused throughout the whole system otherwise enterprises will have the incentives to renege on commitments to the market.

Similarly Hong Kong’s Banking Ordinance requires the cooperation of Banks, particularly those from the Mainland. The problem is that the two banking systems have yet to be fully reconciled. This potentially affects both the effectiveness of the framework, in addition to the regulatory and cross-border aspects of Basel. Therefore 
the existence of an effective framework should not be treated at conclusive. Bearing this in mind, the following sections pay particular attention to aspects of the Principles and Basel recommendations that are less determined by formal compliance.

In an effort to revamp their image and solve their problems, China's state-owned commercial banks have been pursuing international listings in Hong Kong. Similar to the gradualist nature of other reforms, reform of the banking sector followed a cautious and experimental route. The first "experiment" involving the listing of a commercial state-owned bank was the BOCHK. The listing of the BOCHK has since been dwarfed by the subsequent listing of not just its own parent bank the BOC, but also other major state commercial banks (Table 3). Indeed the popularity if not success of the listing of BOCHK can be gauged by the fact that as of June 2007, three of China's four large state-commercial banks had listed H-shares on the HKSE main board. The three banks China Construction Bank (CCB), Industrial Commercial Bank of China (ICBC), and Bank of China (BOC), have raised large amounts of capital and attracted high profile international strategic investors (Table 3). Only the most problematic large state commercial bank, the Agricultural Bank of China (ABC) remained unlisted.

(Insert Table 3 here)

What is significant is how, preparation for listing of the larger state banks led to the uncovering of poor banking practices in the Mainland. For example, in March 2006 it was revealed that five officials at a remote branch of the BOC had embezzled 430 million Yuan. In the run-up to the listing of CCB, its Chairman Zhang Enzhao, was put under investigation for corruption and his predecessor, Wang Xuebing, was jailed for 12 years for offenses committed while he was President of the BOC. ${ }^{3}$ The former head of a branch of ICBC faced a fraud trial on charges of taking bribes worth eight million Yuan. ${ }^{4}$

However these listings also induced important changes. CCB became the first of the "Big-Four" mainland banks to appoint a foreign independent director in advance of its IPO. ${ }^{5}$ Preparation for listing has also resulted in a greater focus on financial returns. Table 4 shows a general improvement in returns across all three listed state banks in the run-up to their IPOs. ${ }^{6}$ Across China's four major state-owned commercial banks, only the unlisted Agricultural Bank did not make available a Tier 1 capital ratio. Even more interesting is that these banks not only disclose their Tier 1 ratio but also comply with 
the minimum ratio set out by the Basel committee. Improvements at the ABC while impressive are not directly comparable to other listed banks, as its results are not subject to the same level of international auditing. In addition its ratio of non-performing loans stood at over $23 \%$ in 2006.

It is worth noting that international listing may not be the key inducement mechanism for this type of disclosure as many of the smaller commercial state banks now provide this ratio. This suggests that there may be a general desire to converge with international best practice. It is however reasonable to suggest that its disclosure is the minimum required for an international listed bank. In the next section we examine the more specific question of how and to what extent these changes can lead to a convergence with international best-practices, not just in terms of corporate governance but also sector specific best-practices.

(Insert Table 4 here)

\section{The BOCKH, international listing and convergence}

Although not many Chinese state banks operate on a major scale in international markets, one well known exception is the BOCHK, the Hong Kong-based subsidiary of the BOC Group. The BOC was somewhat unusual in that unlike other large statecommercial banks, it had a long history of operation in advanced market economies. As such, although it had the same management structures as its mainland counterparts, it also should have had a certain advantage in converging with better practices. The BOC was founded in 1912 and is the second largest bank in China with a market share of about 17\% (Standard \& Poor's, 2003). It has operated in some of the most highly regulated banking environments in the world including London, New York and Hong Kong. In this section we focus on the banks operations in Hong Kong for two specific reasons. The first is that long before China's open door policy, the Bank of China and its sister banks operated in Hong Kong's market economy supplying finance to both Hong Kong and Mainland related projects. This involved the use of innovative financial techniques to circumvent international embargos on Mainland investments (Goodstadt, 2007). Secondly, prior to its IPO in 2002, not much was known about the internal workings of the bank. The bank was typically viewed as a type of anomaly having all the management and risk-control features of a developing economy bank, yet operating in highly regulated and competitive economies (Sun \& Tobin, 2005). The true extent of 
its managerial practices only became apparent in the run-up to the listing of its Hong Kong subsidiary banks in 2002, with the revelation of severe mal-practice in its Hong Kong, New York and Mainland banks.

To understand the institutional constraints facing China's banking system and its Hong Kong subsidiaries it is important to understand the historical background to their operation. Prior to China's open door policy in 1978, the operations of mainland banks in Hong Kong were comparatively small and dispersed, while their business growth and the services they could offer were constrained by political events. Using archival information, Schenk (2007) puts the share of mainland banks at $14 \%$ of Hong Kong deposits in 1966, falling to $9 \%$ by 1972 , with the decline mainly attributed to political events on the mainland. Of the 13 PRC banks in Hong Kong in 1970, the most politically influential was the BOC, but the one with the largest local deposits and advances was Nanyang (Schenk, 2007). Following the open door policy in 1978, the BOC and its sister banks in Hong Kong immediately expanded the range of services they would accept, thereby providing the major competitive threat to Hong Kong banks such as HSBC (Goodstadt, 2005).

The restructuring of the BOC's Hong Kong operations in 2001 not only brought more information into the public domain, but also gave the bank a business structure that was comparable to other large Hong Kong banks by amalgamating the dispersed Chinese banks under one structure. Prior to this, the BOC's Hong Kong operations were made up of Po Sang, which included the former Hong Kong branches of BOC, China South Sea Bank, China State, Kincheng, National Commercial and Yien Yieh. The operations also included the former branches of Hua Chiao, Kwangtung and Sin Hua. The merger of these banks under the BOC (HK) gave the new entity a network of 278 branches in Hong Kong and six branches in Mainland China. The new entity had a $100 \%$ interest in Nanyang Bank, which had a network of 43 braches in Hong Kong, six branches in the mainland China, and one branch in the United States. It also had a majority shareholding in Chiyu (HK), which at the time of listing had 23 branches in Hong Kong and two in Mainland China. Both Nanyang and Chiyu Banks were to continue to conduct their business independently.

\subsection{The corporate Governance framework for state-owned banks}

It is important to note that although the BOCHK had a long history of operating in Hong Kong; it was ultimately a state-owned Chinese bank, run by Chinese directors 
appointed by its parent bank the BOC and with substantial mainland operations. As such, its corporate governance framework was ultimately determined by Mainland China.

Both the OECD and Basel codes emphasise the promotion of efficient and transparent markets, the rule of law and a clear division of responsibilities as a prerequisite for good corporate governance practices. For banks two features central to this are a sound legal system that enforces creditor property rights and a healthy corporate sector. Levine (2003) notes that for corporate governance, a distinguishing factor between banks and other firms is that banks suffer from greater levels of informational asymmetries as loan quality is often not readily observable. One specific example in China is that of the auto industry where a lack of property rights enforcement made it possible for a borrower to acquire auto finance to purchase a car and later resell it in another province claiming the car had been stolen. The borrower can then claim inability to repay. ${ }^{7}$ Lack of legal enforcement also affects the development of a healthy corporate sector as enterprises have a greater incentive to default on repayments. More generally administrative quantity restrictions have proved ineffective for regulating the expansionary behaviour of SOEs. In many cases these have instead led to "cat and mouse games" between local cadres and officials, as central government lack local enforcement capabilities. ${ }^{8}$

More successful has been the establishment of a central bank the PBOC in 1983, and later a regulatory body, the China Banking Regulatory Commission (CBRC) in 2003. ${ }^{9}$ The CBRC has received legal backing to take over the regulatory and supervisory functions of the PBOC. ${ }^{10}$ The PBOC will focus on setting interest rate levels, reserve and liquidity ratios as well as issuing guidelines on credit expansion. Both the CBRC and the PBOC have gone about their functions in a proactive manner. One bank director reported that "at every board meeting, the CBRC guy is right there taking notes and pounding the table”. ${ }^{11}$ The PBOC has issued a set of liquidity ratios similar to central banks in developed economies. In January 2004, the CBRC began phasing out the four-tier loan classification system in favour of the internationally accepted five-tier classification. In March 2004 it announced measures aimed at improving disclosure and transparency in the reporting of NPLs, non-credit assets and off-balance-sheet business. ${ }^{12}$ This laying out of regulations is essentially the first step in the development of a healthy banking system; the second is their implementation and enforcement. 
A major aspect of regulatory enforcement in banking concerns achieving effective monetary transmission, i.e. implementing monetary policies at the micro-level. Rapid economic development in developing economies like China tends to create many incentives for expanding output through investment, but few measures for making borrowers bear the full cost of investing inefficiently (McKinnon, 1991). Many banks have yet to shed their bureaucratic-oriented mentality and their business objectives tend to be more motivated by personal promotion than profit maximisation. ${ }^{13}$ Although the PBOC practices strong control over the interest rate, the adoption in 2004 of a $0.9-1.7$ percentage point floating range has allowed the banks some scope to price loan risk. This requires banks to establish credit rating models based on historical data, calculate risk premiums and financing periods. One critical weakness acknowledged by the PBOC is that years of interest rate controls have given banks little or no market-based experience of loan pricing. ${ }^{14}$ Podpiera (2006) finds that although credit expansion has slowed, the pricing of risk remains undifferentiated and banks do not appear to take account of enterprise profitability when making loans. Zhou Xiaochuan, Governor of the PBOC, has acknowledged that monetary transmission will remain a problem and "only when agencies at the micro level put in place risk control and capital constraint, could monetary policy transmission mechanism work". ${ }^{15}$

\subsection{Rights of shareholders and stakeholders}

The previous section indicates that the state as the majority shareholder enjoys significant power. It also points to weak risk-management practices, limited experience with pricing credit under market conditions and poor disclosure. In terms of stakeholders it suggests that the stakeholders that mattered were large state industrial enterprises. Other stakeholders such as private enterprises, small borrowers and depositors were of limited concern. Taken together these unsurprisingly suggest that China's banks, even when listed abroad, may fall short of the international standards simply because they are constrained by a weak domestic framework.

Given the strong ties between Chinese banks and the state, the question remains as to whether these political connections result in a diminished accountability to minority shareholders and other stakeholders. Preparation for the BOCHK's IPO in Hong Kong induced significant restructuring, including consolidation of the Bank's Hong Kong operations and the institution of a centralised management function. As stated in the listing prospectus, the bank focused on its desire to institute stronger 
governance practices and more stringent risk controls (p. 51). It also came with a commitment for a change in corporate culture. The listing prospectus makes specific reference to maximizing shareholder value (p.52). Although there has been a continued move towards improved practices in China, the explicit statement regarding maximization of shareholder value in an industry previously the bastion of state ownership, can be viewed as an acknowledgement of the change in culture at the bank.

In practice this change was reflected in the reform of the bank's corporate structure, its changing governance practices, and the increasing emphasis on financial returns. The delineation between control and management was made clearer, and more effective risk management processes were put into effect. In addition to the once-off standardisation of governance induced by listing, the decision to list on a developed stock exchange ensured that the Bank would be subject to continuous external monitoring through both the market share price and regulatory authorities, not to mention a vigilant Hong Kong media. Any lack of compliance can be immediately reflected in the market share price. The increasing emphasis on shareholder value is also reflected in the real efficiency improvements achieved by the bank (Table 5). The bank achieved consistent improvements in returns, something Chinese banks have found difficult to achieve. It improved labour productivity as measured by profits per employee, benefiting from a reduction in the overlapping of functions. It also achieved a reduction in the level of classified loans. In addition, the bank has maintained a capital adequacy ratio comparable to international standards.

\section{(Insert Table 5 here)}

\section{An early test: the Shanghai loan scandal}

An early test of the commitment of the BOCHK to minority shareholders was provided in May 2003 when the bank announced that its Chief Executive Liu Jinbao had resigned as part of a routine management change. ${ }^{16}$ Later it emerged that Mr. Liu was being investigated for corrupt lending practices to a well-connected Shanghai property tycoon Zhou Zhengyi, some of which occurred around the time of the bank's IPO. ${ }^{17}$ More significant was that fact that the bank had investigated Mr. Liu’s activities as early as February 2002, but hadn't disclosed this to potential investors in the IPO prospectus. 
The loans to Mr Zhou were indicative of the problems of a weak corporate governance framework. Zhou was one of a large number of new Chinese tycoons who exploited personal connections in order to make fortunes from land deals. ${ }^{18}$ Prior to his arrest, a group of Shanghai residents alleged that Zhou colluded with officials to evict them from prime development land, without fair compensation and that he had also secured a 43,000-square-metre plot for free. ${ }^{19}$ Zhou was arrested on the back of increasing public anger in Shanghai concerning the manner in which officials were transferring land to private developers. ${ }^{20}$ His arrest coincided with efforts to tidy up the loan books of state-owned banks and an acceleration of efforts to adopt international best practices. ${ }^{21}$ Zhou was accused of securing 650 million Yuan in loans through unorthodox methods from Shanghai-based financial institutions. These were acquired through subsidiaries of his HKSE listed Shanghai Land Holdings. Zhou secured HK\$2.2 billion in loans from the BOCHK in order to fund his takeover of Shanghai Land Holdings using his shares in Shanghai Land Holdings as collateral for the loan. Although not specifically breaking any laws, the practice of making loans with shares as collateral, went against international best practices. Moreover, the BOCHK had vowed that such practices were a thing of the past,

From a shareholder perspective, the case illustrated the great difficulties faced by China in converging with western best-practices. The case involved both the Chinese and Hong Kong regulatory systems. Shanghai Land Holdings was listed on the HKSE and therefore subject to its regulatory authority. The task of protecting shareholder's rights in Hong Kong companies that have the bulk of their operations and assets in Mainland China is made more complicated by the difficulty in establishing the rights of competing claimants and subsidiaries. This is particularly problematic in Mainland companies where property rights are less well defined.

The bank responded by reassuring investors that the scandal would not adversely affect profitability. It also claimed that its audit committee had carried out a review of the loan and that it was granted in accordance with the bank's credit risk management policies and procedures. ${ }^{22}$ The slow response of the bank not only contravened Hong Kong's regulations on timely disclosure, but was also a breach of investor trust. Standard and Poors, a leading international credit ratings agency, revised its BBB-plus long-term counterparty rating from stable to negative, based on concerns over the bank's credit approval process. ${ }^{23}$ As a result of numerous other downgrades and negative coverage, the share price started to lag the index of Hang Seng financials. ${ }^{24}$ 
After it became apparent that Mr. Liu was subject to a formal investigation by authorities in Beijing, the BOCHK announced that it would carry out a more thorough investigation into its internal risk-management and credit approval procedures. ${ }^{25}$ This investigation would involve a special committee chaired by an international adviser with the power to engage external advisors and auditors. The investigation would go beyond the Shanghai loan and would examine much broader lending practices. The bank carried out discussions with the HKMA over how best to conduct the investigation. The bank agreed to carry out an interim audit and a special review of lending practices (by an independent auditor). This was almost a re-run off the initial due-diligence process. This was not required by the HKMA or HKSE, but represented a voluntary commitment by the bank in response to market concern.

\subsection{Disclosure and transparency}

As one of Hong Kong's three note-issuing banks, the BOCHK was under particular pressure to be transparent. The IPO process put the reputation of the bank on the line. The overlooking of any aspect of the due-diligence process could have caused huge public embarrassment to the bank. Indeed the uncovering of poor disclosure practice post-IPO did prove very embarrassing for the reputation of the bank, not just in terms of media coverage, but also in terms of its business reputation. In addition a review of the bank's operations revealed that although it complied with Hong Kong's regulations, its application was inconsistent, further suggesting that the essence of good governance is in doing the right thing, even when no one is looking.

One of the transparency problems associated with the Mainland-banking sector is the inconsistent application of loan classification criteria. As part of the preparations for its IPO, auditors carried out a thorough examination of the bank's loan portfolio. This placed emphasis on China related loans greater than HK\$20 million, loans that had recently been restructured and the loan classification system. The audit found that although the bank complied with the HKMA's guidelines on loan classification, the implementation of these guidelines was inconsistent. In response, the BOCHK further defined the way in which it classified loans beyond what was required by the HKMA. The IPO process indirectly allowed the bank to improve loan classification across the newly consolidated group of banks. Prior to the IPO, Hong Kong banks within the BOC group competed with each other to make loans. A borrower could default on one 
bank but continue to repay the others. As a consequence, the application of loan classification criteria tended to be inconsistent.

Greater consistency led in turn to a greater level of transparency regarding the level of risk facing the bank and how it compared to its peers in Hong Kong. This revealed how the BOCHK had a much higher level of classified loans than its Hong Kong counterparts, despite operating in the same market. It also illustrated the level of exposure to such volatile sectors as the Hong Kong property market. For example, $49.7 \%$ of the banks classified loans and $32.2 \%$ of total loans were in Hong Kong's property sector. It also revealed how exposed the bank was to the mainland economy. Over $43 \%$ of the bank's Mainland loans were classified loans, compared to $10.9 \%$ of its Hong Kong loans. This indicated that loan portfolios in China, even in better-regulated banks such as the BOCHK, historically have a greater percentage of bad loans.

The process of related or connected party transaction has been made somewhat more transparent by the listing regulations of the Hong Kong stock market. These require that all connected party transactions above a certain value must be disclosed to the stock exchange and voted upon by minority shareholders. The connected parties are not allowed vote. For the BOCHK this means that any transactions or asset transfers above a certain value need to be disclosed and approved by minority shareholders.

\subsection{Prudential regulation, risk management and remedial action}

The effectiveness of prudential regulation is at the centre of the Basel framework and is also a major part of the corporate governance framework outlined by the OECD. Principle Seven of Basel outlines that supervisors must be satisfied that banks have in place a comprehensive risk management process appropriate to the size and complexity of operation. Principles Eight and Nine deal with the processes to manage credit-risk and asset quality, while Principle 17 focuses on how supervisors must be satisfied with internal audit and control structure. Principle 23 focuses on the remedial action of supervisors. We have already seen that there are many weaknesses in China's domestic system of prudential regulation. In theory these should be mitigated by international listing. In practice, the Shanghai loan scandal showed that while international listing can induce greater transparency, the granting of the loan highlighted serious deficiencies in risk management and raised questions regarding the remedial action available.

The major question therefore for China's internationally listed banks is to what extend the level of prudential regulation in Hong Kong can compensate for weak 
Mainland regulation. The BOCHK is unique in this regard as it is the only one of the large state-owned banks with significant banking operations in Hong Kong. As such it was also subject to Hong Kong's banking ordinance. What is interesting about the BOCHK is that it suggested that the prudential regulation of the bank's operations only became an issue after the listing on the HKSE. In other words, Hong Kong's banking ordinance did not require the bank to make significant disclosures on its risk management or credit approval procedures. Neither as it turned out was it able to enforce remedial action on the bank. Most of the remedial action stemmed from the banks own internal efforts and voluntary cooperation with the HKMA. To examine this question in more detail the following outlines in more detail the information on risk management practices and the remedial action available that became apparent after the BOCHK’s listing in Hong Kong.

\section{Risk management}

In terms of the approval of the Shanghai loan, it appears that political considerations were placed above the economic functions of screening and monitoring. The report by the Special Committee examining the granting of the loan was particularly critical. It noted that Mr. Liu as Chairman of the BOCHK had failed to intervene in the transaction even though he knew there were serious reservations that had not been satisfied. ${ }^{26}$ It also noted the failure of Mr. Liu to recognise the weakness in the system of checks and balances. According to the report, Mr. Liu should have also recognised that the de facto chairman of the Credit Committee, Mr. Or, was responsible for both business generation and risk management, which would ultimately impede the Credit Committee's effectiveness in deciding on a loan that Mr. Or had already approved. Political considerations aside, the loan also went against all business logic.

“... BOC was willing to not only extend a loan on risk collateral, but to allow $100 \%$ financing against this collateral (shares in Shanghai Land), when the normal loan-tovalue for stock based lending would be more like $10 \%$ [for a speculative stock] to $60 \%$ [for a blue chip stock]" 27

The case ultimately shed light on the serious lack of adherence to good banking practice. In a western bank there would be no conceivable reason for granting such a loan. As noted by a senior Hong Kong banking executive, this is not how professional 
banks are run. ${ }^{28}$ In any other bank, such a loan would not have gone through if Mr. Liu had such reservations. The problem is that it was politically convenient for Mr. Liu not to take responsibility. Granting the loan kept political favour with Mr. Zhou, the Shanghai tycoon. From a best practice perspective, the meeting with Zhou should have been cancelled and the loan declined, because Mr. Liu should have been accountable for what happened on his watch. In effect, Mr. Liu was able to use political discretion to renege on ex-ante commitments to the market. The implication is that even after listing managers can still behave opportunistically as there are two systems of governance in operation. One system is answerable to the market, the other to Beijing.

\section{Remedial Action}

Directors' close connections with Beijing are always likely to be problematic in terms of enforcing remedial action. This is because Beijing directors are ultimately responsible to a different system of rules based on political considerations. The recall of Mr. Liu in 2003, and the recall of two deputy chief executives in August 2004, illustrates how the two systems have yet to be reconciled. Mr. Liu was not officially sacked until February 2004 and was put under investigation for such "economic" crimes as accepting bribes and issuing bad loans during the period 1993 to 1997. Authorities in Hong Kong had no opportunity to investigate Mr. Liu’s actions. An official at the HKMA reported that he was as baffled as the public on Mr. Liu's situation. ${ }^{29}$ Hong Kong's banking industry was reported as hoping that the HKMA could use meetings with their counterparts at the CBRC in Beijing to shed some light on the scandal. ${ }^{30}$ Apart from a letter to the HKMA on the $13^{\text {th }}$ June 2003 confirming his resignation from Hong Kong's Exchange Fund Advisory Committee, effective from the $28^{\text {th }}$ May $2003,{ }^{31}$ Mr. Liu had little or no contact with the HKMA. This proved problematic for regulators in Hong Kong, as mainland probes into officials tend to take months to complete, with political considerations carefully weighed against any financial and legal implications. ${ }^{32}$

The abrupt resignation of two deputy chief executives in August 2004 was surrounded in similar uncertainty. Two of the banks deputy chief executives, Mr. Zhu Chi and Mr. Ding Yanshang, were suspended and transferred to Beijing to be investigated by local authorities for allegedly misappropriating shareholders funds for personal purposes. ${ }^{33}$ The fraud was alleged to have taken place prior to the Bank's IPO in 2002. The big question for shareholders was why it took the bank so long to uncover the scandal. Unfortunately for shareholders, there were few answers to these questions. 
Again the handling of the case illustrated a clear gap between the level of accountability investors in a developed market expect from a bank such as the BOCHK and the tradeoffs faced by the mainland in converging towards better corporate governance.

\subsection{Board of directors - responsibility and independence}

The OECD principles emphasise the accountability, independence, and transparency of the board of directors. Principle Three of Basel suggests that the licensing process should include an assessment of the propriety of Board members and the governance structure. This demand has the potential to create significant difficulty for state-owned banks whose long history in the state bureaucracy imply that they are more accountable to political authorities than market shareholders. In addition bank management tend to be drawn from a small pool of closely connected directors. While there is strong evidence to support this view, the experience of the BOCHK listing also suggests that despite the above constraints, there is evidence that directors are increasingly aware of market perceptions. A significant influence in this change is the role of independent foreign directors. As such, while a dual system of governance may be inevitable in the short term, the case of the BOCHK suggests that directors are likely to become increasingly accountable to the market for their actions.

The BOCHK listing prospectus indicates that regardless of implementation, there was an effort to adopt certain principles of better governance. The BOCHK's board consists of 13 members, six of which are non-executive directors, one is an executive director and the remaining six are made up of independent non-executive directors (INEDs). The inclusion of independent directors is seen as a means of providing independent oversight and minority shareholder protection and the bank has its own policy director independence, which it believes is more stringent than HKSE requirements.

Not only did the BOCHK appoint a comparatively large number of independent directors, but it also gave them unprecedented levels of responsibility. After the revelations of wrong-doing by senior members of management in 2003, independent directors were given a "free hand" to examine the risk management procedures of the bank. In June 2003, the Bank announced the formation of a special committee consisting of two independent directors and an international-banking expert, to undertake a comprehensive review of the credit approval processes and risk management and internal control mechanism of the Bank. ${ }^{34}$ Giving “outsiders” free 
scope to examine and report on internal management and risk control issues was unprecedented in China's banking sector. The Bank has also drawn on "outsider" expertise to search for external replacements for deputy chief executives who resigned following another scandal in 2004. Since 2004 it has been bank policy to involve independent directors in the recruitment of senior management. ${ }^{35}$ These appointments have made life much easier for the "Beijing" directors. According to the bank, independent directors have been responsible for initiating many of the changes in how it operates, particularly changes in governance becoming an important catalyst for change at the bank.

Yet despite these changes there are also certain limitations on the overall independence of the board. The strength of the government's shareholding in comparison to minority shareholders is great, preventing minority shareholders from having any meaningful effect on the bank. BOC, the BOCHK's state-owned parent company completed its own IPO on the Hong Kong stock market in 2006. What is not clear, despite the reassurances given to the stock market is how this relationship ultimately affects board independence. Nolan (2001) notes that the state's policy of creating such large-scale entities, accompanied by the growth of smaller subsidiary units, has created some confusion regarding where is the firm. It is not clear for example if the BOCHK will eventually become irrelevant within the lager BOC group?

In terms of director appointments, although the bank ticks all the boxes in terms of having a nomination committee, the state ultimately dominates the selection process. After listing, six of the seven non-independent directors concurrently held senior executive positions at the BOC. All non-independents had in the past held positions within the BOC. Ultimately these directors have the final say over policy. Mr. Liu's original resignation was presented as a routine switch of personal in the BOC group. ${ }^{36}$ Mr. Xiao Gang was appointed Chairman and Chief Executive of the BOC as a result of Mr. Liu Mingkang's appointment to the CBRC. Mr. Xiao was also appointed to the position of chairman of the BOCHK.

Further questions regarding the independence of the board of directors are revealed by the close ties between China's top bankers, and the relatively small pool of talent from which the sector can draw upon. Liu Mingkang, the chairman of the CBRC, is in charge of investigations into corruption in the banking sector. He was also Liu Jinbao's boss at the BOCHK. Wang Xuebing, the disgraced banking executive for the BOC (New York), was also a colleague of both Liu Mingkang and Liu Jinbao. The 
result is a small group of closely connected officials, which creates significant opportunities for moral hazard. Ultimately recruitment to senior directorships in the mainland state banking sector is still based on political and strategic considerations.

Similar difficulties are also evident in remuneration structures. It is inherently difficult for the BOC to have one pay level for bank directors and staff on the mainland and another for Hong Kong staff. Such issues have their roots in central planning where the pay levels were supposed to be equal and the party took care of welfare after retirement. However directors are likely to become accustomed to a higher standard of living in Hong Kong. A CLSA (2004) report on corporate governance in Hong Kong criticised the BOCHK's low remuneration of directors and recommended that the bank take steps to create competitive remuneration structures in order to lessen the incentives for corruption. ${ }^{37}$ Ultimately, directors that are appointed and remunerated by the state are ultimately more accountable to the state. As a result, a dual system of governance may be inevitable.

\section{Adaptation: efforts, achievements and shortfalls}

In examining the extent to which Chinese banks are converging with international best banking and corporate governance practices, much of the focus revolved around whether, in the absence of full domestic convergence, banks could use Hong Kong's institutional framework as a means of achieving convergence. The case of the BOCHK suggests that formal convergence is indeed possible in terms of listing and capital requirements, general regulatory compliance and board structure. More difficult to achieve is a substantive convergence. These concern areas such as risk-management and remedial action, which ultimately depend on the integrity of directors and their supervisors. While these finding are consistent with the literature emphasising the domestic governance framework (e.g. Black, 2001), neither can the important elements of convergence, be overlooked. This section discusses the achievements of international listing, its limitations, and the challenges remaining.

On a formal level, the increased emphasis on shareholder value has brought the BOCHK much closer to its Hong Kong counterparts and further distanced it from the conventional concept of a state-run bank. Table 6 indicates that across a range of performance indicators, the BOCHK is now more comparable to its large Hong Kong competitors such as HSBC, than its mainland counterparts. Indeed comparing its current performance to that prior to its IPO when it was more comparable to the other Mainland 
state banks (see Table 5), it is clear that international listing has provided a powerful inducement for change at the bank.

(Insert Table 6 here)

Similarly, the eagerness of the BOCHK and other state-owned commercial banks to learn from and integrate international best practice became more urgent as a result of the unearthing of weak management practices. The BOCHK argue that their attitude since listing has been to do the right thing at all costs. ${ }^{38}$ This underpinned the decision to carry out a thorough audit of lending practices after the Shanghai loan revelations. For the "Beijing" directors this has involved a steep learning curve in market discipline. Even allowing for constraints in the institutional framework, the bank notes that the directors of state banks have a strong incentive to be professional, as good compliance puts directors in a good light.

Yet, one of the limitations of international listings is that although it puts in place a strong monitoring mechanism to enforce commitment, it cannot completely prevent management from behaving opportunistically.

“...Despite reforms, government officials will still act unreasonably...adopting best practices can make life easier for directors”39

What it does achieve is that it allows directors a good excuse for not engaging in corrupt practices. The uncovering of corrupt practices post-listing in the BOCHK suggest that despite the commitment to better practices, management still enjoy a limited degree of discretion and are constrained by weaknesses in the domestic corporate governance framework.

What is interesting about the problems faced in China, particularly in the area of board independence, is how they differ conceptually from governance problems in developed economies. Close connections with the state paradoxically create stability and security for the major stakeholders in China's banks, namely their depositors. The credit-support ratings of the large state banks indicate that state support for depositors remains very strong, though support for other creditors is less certain. ${ }^{40}$ Such interference in developed economies would be regarded as poor governance practice. Control over appointments ultimately ensures that banks are accountable to their major shareholder - the state. Similarly, while Feinerman (2007, p. 610) argues that China has 
much progress to achieve in terms of executive compensation procedures, evidence from the BOCHK suggests that compensation is not an issue particularly when compared to the levels of salaries earned by the directors of Hong Kong's major banks. One could conceivably argue that the remuneration structures in place are consistent with that of a state-owned bank.

A more pressing problem therefore is not so much whether remuneration has been brought into line with international standards, but rather whether or not Chinese banks have the autonomy to implement best-practices in a way that are consistent with domestic conditions. The financial returns of China's state banks, although improving, are still well-short of international levels. To this extent domestic conditions still matter. Vice-Premier Huang Ju noted that banking supervisors need to learn from best international practices so as to explore a route of supervision that complies with both China's real conditions and international norms. ${ }^{41}$ The CBRC for its part has made the adoption of international best practice a priority, particularly in the case of the BOC and CCB, with both banks regarded as pilot experiments in best practices. ${ }^{42}$

\section{Conclusions}

This study has shown that while domestic institutional structures matter, international listing can mitigate many of the constraints to best practice in China's state banking sector by not only imposing a more consistent set of rules, but also providing the incentives for convergence. However, the disciplining effect of international listing cannot be taken as a given. It must be accompanied by a substantive firm-specific commitment to integrating better practice. International listing is not a substitute for real improvements, but must form part of an integrated approach to realising the professional competencies of management.

In the case of the BOCHK initial revelations of poor practice as part of preparation for the IPO showed that although the bank’s management had a long history of operating to international standards, there still existed a considerable mismatch between these experiences and what the Hong Kong market demanded. Compliance with the disclosure requirements of the HKSE and the disciplines of the market that followed, were undoubtedly significant learning experiences for the bank's directors. This, along with the improvements achieved in other state banks suggests that international listing and the exposure to international standards can act as a powerful incentive for integrating best-practices. 
It could be argued that the BOCHK is an exception to the other Chinese state banks. The bank operates in Hong Kong, a leading financial centre. It operates under different regulatory environment to other state banks. Its quality of assets is better. The press in Hong Kong are more vigilant and sensational than their Chinese counterparts. Yet, it is significant that many of the BOCHK management practices were similar to those of Mainland banks. It is therefore possible that international listing can achieve a level of international best practice in China's banks. Interestingly the BOCHK sees no reason why the restructuring it achieved cannot be repeated in other state banks. However, it acknowledges that for this to happen, there must be a wholehearted commitment by the board of directors and the parent company to adopting international standards. A senior executive at the bank noted that "it is one thing to pay lip service and tick the boxes, but it is another thing for the board at the parent company to allow them (the listed company) room and the authority to function". ${ }^{43}$ 
${ }^{1}$ For example in 2005, Transparency International ranked Hong Kong $15^{\text {th }}$ in the world in terms of integrity, while China was ranked 82 ${ }^{\text {nd }}$. "Integrity and Corruption” The Economist October $20^{\text {th }} 2005$.

${ }^{2}$ Interview HKSE, $22^{\text {nd }}$ July 2001, and HKSFC, $5^{\text {th }}$ July 2004. The HKSFC noted that the process of regulation is however likely to become more prudential with regulations on transparency and disclosure being put in stature to bring the Hong Kong market in line with international practice. The likely effect for Mainland companies is that they will have to think even more seriously about regulatory risk.

3 "Graft investigation clouds Construction Bank plans to list in SAR" The Standard (HK) $16^{\text {th }}$ March 2005.

4 "Banker gets six years in 38m Yuan loans scandal” The Standard (HK) $2^{\text {nd }}$ February 2005.

5 “Shinsei Chief named CCB’s independent director” Financial Times $(F T)$ 22 ${ }^{\text {nd }}$ September 2004.

${ }^{6}$ Given the numerous state asset injections and earnings restatements that took place over the last few years, the financial returns of state banks need to be interpreted cautiously.

${ }^{7}$ Interview: Director, DSG Asia, Hong Kong, 23 ${ }^{\text {rd }}$ August 2004.

8 “Beijing to step up fight on illicit steel plants" FT 24 $4^{\text {th }}$ September 2004.

${ }^{9}$ While the PBOC was originally formed in 1948, it was not until 1983 that the State Council decided that it should function as a central bank. This status was not recognised in law until1995.

${ }^{10}$ The PRC law on banking supervision, effective from the $1^{\text {st }}$ February 2004 clarifies the legal status of the CBRC giving it broad supervisory powers over commercial banks.

${ }^{11}$ Stephen Harner, Independent Director, Hangzhou City Commercial Bank quoted from The Economist, $27^{\text {th }}$ October 2005.

12 “Banks must be transformed” FT, $5^{\text {th }}$ May 2004.

13 "Some Considerations in the Study of Monetary Policy Transmission" Zhou Xiaochuan Governor, PBOC, $12^{\text {th }}$ May 2004

${ }^{14}$ China's Monetary and Interest Rate Policy in Year 2004, PBOC 12 May 2004.

15 "Some Considerations in the Study of Monetary Policy Transmission” Zhou Xiaochuan Governor, People's Bank of China, $12^{\text {th }}$ May 2004

${ }^{16}$ BOCHK Announcement Change of Chairman and Chief Executive $28^{\text {th }}$ May 2003.

${ }^{17}$ See "Bad Habits” The Economist $12^{\text {th }}$ June 2003.

18 “Scandal in Shanghai” The Economist, 16 ${ }^{\text {th }}$ August 2003.

19 “Shanghai vows to crack down on property bribery" South China Morning Post (SCMP), $13^{\text {th }}$ June 2003.

${ }^{20}$ Between 100 and 200 peoples were reported as having been involved in a protest outside a local government office over the issue of land transfers. An official from the Shanghai government claimed that over million people had been moved to make way for redevelopment since the 1990s. "Shanghai Police arrest property protesters” SCMP, $18^{\text {th }}$ June 2003. 
${ }^{21}$ A special investigation by the Peoples Bank of China in 2002 into the lending problems of state-owned banks resulted in the censoring of 114 people responsible for loan management, 15 of whom were handed over to the courts. "Bank officials punished for malpractice" China Daily, 17 $7^{\text {th }}$ June 2002.

${ }^{22}$ BOCHK Announcement relating to the New Nongkai Loan, $7^{\text {th }}$ June 2003.

23 "Control concerns spurs S\&P to downgrade BOCHK” SCMP 12 ${ }^{\text {th }}$ June 2003.

24 “List of Downgrades Continues" SCMP, $5^{\text {th }}$ June 2003.

${ }^{25}$ BOCHK Announcement, 11 ${ }^{\text {th }}$ June 2003.

${ }^{26}$ BOCHK Announcement: Report of the Special Committee on Corporate Governance, Credit Approval Process, Risk Management \& Internal Control Mechanisms of BOCHK Ltd, $5^{\text {th }}$ Sept 2003.

${ }^{27}$ Roy Ramos (Goldman Sachs) quoted in "Listing Sponsors go negative on BOC" SCMP, $10^{\text {th }}$ June 2003.

${ }^{28}$ Interview: Deputy Chief Executive, Hang Seng Bank, $5^{\text {th }}$ August 2004.

${ }^{29}$ HKMA Deputy Chief Executive HKMA as reported in SCMP $14^{\text {th }}$ June 2003.

${ }^{30}$ Reported in SCMP $14^{\text {th }}$ June 2003.

${ }^{31}$ Government Information Service, Hong Kong, $13^{\text {th }}$ June 2003.

${ }^{32}$ See "HKMA widens the Net in BOC Probe" The Standard (HK), 6 ${ }^{\text {th }}$ August 2004.

33 “Lender hit by new scandal” The Standard (HK), $4^{\text {th }}$ August 2004.

${ }^{34}$ BOCHK Announcement 10 ${ }^{\text {th }}$ June 2003.

${ }^{35}$ BOCHK Press Release $16^{\text {th }}$ August 2004.

${ }^{36}$ BOCHK Announcement Change of Chairman and Chief Executive $28^{\text {th }}$ May 2003.

${ }^{37}$ The BOCHK’s CEO was paid HK\$2.5 million in 2003 compared with Bank of East Asia’s Chief Executive (HK\$17.5million) and Hang Seng’s Chief Executive (HK\$7.7million). CLSA (2004).

${ }^{38}$ Interview: Executive Director, Bank of China (Hong Kong), Hong Kong, 20 ${ }^{\text {th }}$ July 2004.

${ }^{39}$ Interview: Senior Chinese Bank official, Hong Kong, July 2004.

${ }^{40}$ Fitch Ratings Chinese Banks 2006.

41 “Vice premier emphasizes introduction of best banking practice” Peoples Daily $1^{\text {st }}$ July 2004.

42 "Guidelines on Corporate Governance Reforms and Supervision of Bank of China and Construction Bank of China” CBRC 11 ${ }^{\text {th }}$ March 2004.

${ }^{43}$ Interview: Secretary to the Board of Directors, Bank of China (Hong Kong), Hong Kong, $20^{\text {th }}$ July 2004. 


\section{References:}

Arun, T. \& Turner, J. (2004) Corporate Governance of Banks in Developing Economies: Concepts and Issues, Corporate Governance, 12 (3), pp. 371-377

Bank for International Settlements (2006) Core Principles for Effective Banking Supervision, Basel Committee on Banking Supervision, October 2006.

Black, B. (2001) Does Corporate Governance Matter? A Crude Test Using Russian Data, University of Pennsylvania Law Review, 149, pp. 2131-2150.

BOC Hong Kong (Holdings) Limited (2002) IPO Prospectus [Online] Available: http://www.hkex.com.hk/listedco/listconews/sehk/20020715/LTN20020715047.htm

CLSA, (2004) CLSA Corporate Governance Watch, CLSA September 2004.

Coffee, J. (2001) The Rise of Dispersed Ownership: The Roles of Law and the State in the Separation of Ownership and Control, The Yale Law Journal, 111 (1), pp. 1-82.

Feinerman, J.V. (2007) New Hope for Corporate Governance in China? The China Quarterly, 191 (September), pp. 590-612.

Fitch Ratings (2005) Chinese Bank: 2004 Review and 2005 Outlook, Hong Kong.

Fitch Ratings (2006) China Special Report, $13^{\text {th }}$ December 2006, Hong Kong.

Fitch Ratings (2007) Hong Kong Banks - H107 Results \& Outlook, 29 $9^{\text {th }}$ October 2007, Hong Kong.

Goodstadt, L.F. (2007) Profits, Politics and Panics: Hong Kong's Banks and the Making of an Economic Miracle, 1935-1985 (Hong Kong: Hong Kong University Press).

Goodstadt, L.F. (2005) Uneasy partners: the conflict between public interest and private profit in Hong Kong (Hong Kong: Hong Kong University Press).

Hansmann, H. (1996) The Ownership of Enterprises (Cambridge, MA: The Belknap Press of Harvard University).

Hope, N. \& Hu, F. (2006) Reforming Chinese banking: how much can foreign entry help? Center for International Development, Stanford University. Working Paper No. 276.

Klapper, L., \& Love, I. (2004) Corporate Governance, Investor Protection, \& Performance in Emerging Markets, Journal of Corporate Finance, 10 (5), pp. 703-28.

Korczak, P., \& Bohl, M. (2005) Empirical Evidence on Cross-Listed Stocks of Central and Eastern European Companies, Emerging Markets Review, 6 (2), pp. 121-37.

LaPorta, R. Lopez-DeSilanes, F. Shleifer, A. \& Vishny, R. (2000) Investor Protection \& Corporate Governance, Journal of Financial Economics, 58 (1), pp. 3-27.

Madera, S. \& Sun, L, (2005) International Listing Induced Improvements in Corporate Governance Practices: The Case of China Mobile (Hong Kong) [Online]. Available at: http://www.cefims.ac.uk/cgi-bin/research.cgi?id=48

McKinnon, R. (1991) The Order of Economic Liberalization: Financial Control in the Transition to a Market Economy (London: John Hopkins University Press). 
Nolan, P. (2001) China and the Global Business Revolution (Palgrave: Basingstoke).

Organisation for Economic Corporation \& Development (2004) The OECD Principles of Corporate Governance (Paris: OECD).

Pagano, M., Roell, A., \& Zechner, J. (2002) The Geography of Equity Listing: Why do Companies List Abroad? The Journal of Finance, 57 (6), pp. 2651-2694.

Schenk, C. (2007) Economic and Financial Integration between Hong Kong and Mainland China before the Open Door Policy 1965-75. Hong Kong Institute of Monetary Research: https://www.hkimr.org/conferences_detail.asp?id=27\&callfrom=previous\&page=1

South China Morning Post (SCMP) www.scmp.com

Sun, L. (2003) Ownership and Governance of Enterprises: Recent Innovative Developments (London: Palgrave Macmillan Pres).

Sun, L., \& Tobin, D. (2005) International Listing as a Mechanism of Commitment to More Credible Corporate Governance Practices: the case of the Bank of China (Hong Kong), Corporate Governance: An International Review, 13(1), pp. 81-91.

The Economist www.economist.com

The Standard (Hong Kong), www.thestandard.com.hk.

Tobin, D. \& Sun, L. (2007) International Listing as a Means to Improve the Benefit-Risk Calculus of Financial Globalisation: Micro-Level Evidence from China, CeFIMS Discussion Paper 79. http://www.cefims.ac.uk/documents/research-72.pdf 
Table 1: Summary of Core Principles for Effective Banking Supervision

\begin{tabular}{|c|c|c|}
\hline Category & $\begin{array}{l}\text { Principles } \\
\text { Concerned }\end{array}$ & Major Contents \\
\hline Objectives & Principle 1 & $\begin{array}{l}\text { Objectives } \\
\text { Independence } \\
\text { Powers } \\
\text { Transparency } \\
\text { Cooperation }\end{array}$ \\
\hline Licensing and Structure & Principles 2 to 5 & $\begin{array}{l}\text { Permissible Activities } \\
\text { Licensing Criteria } \\
\text { Transfer of Ownership } \\
\text { Major Acquisitions }\end{array}$ \\
\hline Prudential Regulation & Principles 6 to 18 & $\begin{array}{l}\text { Capital Adequacy } \\
\text { Risk (Credit \& management) } \\
\text { Problem Assets } \\
\text { Exposure (incl. Related Parties) } \\
\text { Country-, transfer-, market-, Liquidity-, } \\
\text { operational- and interest rate-risks } \\
\text { Internal Controls \& Audit } \\
\text { Abuse of Financial Services }\end{array}$ \\
\hline Ongoing Supervision & Principles 19-21 & Supervisory Approach, techniques and reporting \\
\hline Accounting \& Disclosure & Principle 22 & Accounting \& Disclosure \\
\hline Powers of supervisors & Principle 23 & Corrective \& Remedial Powers \\
\hline Cross-border supervision & Principles 24-25 & Home-host relationships \\
\hline
\end{tabular}

Source: Basel Committee on banking Supervision October 2006

Table 2: Equity Funds Raised by Listing on Hong Kong Stock Exchange, 1993-2007 (HK\$ million) $)^{\mathrm{a}}$

\begin{tabular}{rrrrr}
\hline Year & No of IPOs & $\begin{array}{c}\text { Fund raised on } \\
\text { IPOs }\end{array}$ & $\begin{array}{c}\text { Fund raised post } \\
\text { IPOs }\end{array}$ & Total fund raised \\
\hline 1993 & & $9,092.04$ & 14128.71 & 23220.75 \\
1994 & 10 & $11,421.18$ & 11685.17 & 23106.35 \\
1995 & 2 & $3,581.10$ & 6083.86 & 9664.96 \\
1996 & 12 & $10,261.46$ & 16619.31 & 26880.77 \\
1997 & 25 & $71,432.34$ & 42636.69 & 114069.04 \\
1998 & 3 & $2,214.74$ & 18712.63 & 20927.37 \\
1999 & 7 & $6,249.22$ & 53191.82 & 59441.04 \\
2000 & 5 & $95,847.15$ & 249562.21 & 345409.36 \\
2001 & 6 & $17,630.92$ & 7518.44 & 25149.36 \\
2002 & 5 & $37,824.16$ & 31771.67 & 69595.83 \\
2003 & 11 & $49,214.99$ & 2522.19 & 51737.18 \\
2004 & 12 & $54,565.38$ & 31046.63 & 85612.01 \\
2005 & 13 & $138,222.23$ & 42846.02 & 181068.25 \\
2006 & 19 & $292,790.48$ & 61800.44 & 354590.92 \\
$2007^{\mathrm{b}}$ & 8 & $52,687.69$ & 43003.56 & 95691.25 \\
\hline
\end{tabular}

Note: ${ }^{\text {a }}$ Including both H-share listing of enterprises incorporated in China and "red chips" listing of Chinese enterprises incorporated in Hong Kong. ${ }^{b}$ Provisional figures up to August 2007. Source: China Dimension in Data and Statistics of Hong Kong Sock Exchange’s website, http://www.hkex.com.hk/. 
Table 3: Listing of state-owned commercial banks in Hong Kong

\begin{tabular}{l|lccl}
\hline Bank & \multicolumn{1}{l}{$\begin{array}{l}\text { Date } \\
\text { Listed }\end{array}$} & $\begin{array}{l}\text { Capital } \\
\text { Raised }\end{array}$ & $\begin{array}{l}\text { Floated } \\
(\%)\end{array}$ & Strategic Foreign Investors \\
\hline BOCHK & Jul/25/2002 & US\$ 2.7 bill. & 24.2 & Standard Chartered (UK) \\
CCB & Oct/27/2005 & US\$ 9.2 bill. & 12.0 & Bank of America \\
BOC & Jun/01/2006 & US\$ 11.2 bill. & 10.5 & Royal Bank of Scotland, UBS \\
ICBC & Oct/27/2006 & US\$ 21.9 bill. & 15.0 & $\begin{array}{l}\text { Goldman Sachs, American } \\
\text { Express, Allianz }\end{array}$ \\
\hline
\end{tabular}

Source: Various media reports.

Table 4: Return on Average Assets (ROAA) and Tier 1 Capital of Sate Banks

\begin{tabular}{lllll|llll}
\hline Year & $\begin{array}{l}\text { BOC } \\
\text { ROAA }\end{array}$ & $\begin{array}{l}\text { CCB } \\
\text { ROAA }\end{array}$ & $\begin{array}{l}\text { ICBC } \\
\text { ROAA }\end{array}$ & $\begin{array}{l}\text { ABC } \\
\text { ROA }\end{array}$ & $\begin{array}{l}\text { BOC } \\
\text { Tier 1 }\end{array}$ & $\begin{array}{l}\text { CCB } \\
\text { Tier 1 }\end{array}$ & $\begin{array}{l}\text { ICBC } \\
\text { Tier 1 }\end{array}$ & $\begin{array}{l}\text { ABC } \\
\text { Tier 1 }\end{array}$ \\
\hline 2000 & 0.37 & 0.36 & 1.28 & - & & & & \\
2001 & 0.32 & 0.20 & 1.03 & - & & & & \\
2002 & 0.40 & 0.15 & 1.08 & 0.37 & 7.85 & 5.78 & 5.46 & - \\
2003 & 0.74 & 1.13 & 0.94 & 0.56 & 7.11 & 5.88 & 4.77 & - \\
2004 & 0.66 & 1.35 & 0.65 & 0.80 & 8.48 & 8.57 & n.a. & - \\
2005 & 0.70 & 1.11 & 0.66 & 0.89 & 8.08 & 11.08 & 8.11 & - \\
2006 & 0.96 & 0.92 & 0.71 & 1.09 & 11.44 & 9.92 & 12.23 & - \\
\hline
\end{tabular}

Notes: ROAA $=(\mathrm{PBT} /(($ Assets at beginning of Period + Assets at end of period $) / 2)) * 100 . \mathrm{ROA}=$ (PBT/Total Assets)*100. Data for BOC, CCB and ICBC sourced from audited Annual Reports. Comparable independently audited data was not available for ABC.

Source: Bank of China, China Construction Bank (CCB), Industrial \& Commercial Bank of China (ICBC) Financial Reports 2000-2006; Agricultural Bank of China (ABC) Financial Reports, 2004-2006; and Fitch Ratings (2005) 
Table 5: Efficiency and financial indicators for BOCHK

\begin{tabular}{lrrrrrrr}
\hline & 1999 & 2000 & 2001 & 2002 & 2003 & 2004 & 2005 \\
\hline Pre tax profits (HK\$ mill) & 3,771 & 6,376 & 3,733 & 8,068 & 8,691 & 14,252 & 16,368 \\
Return on average total assets (\%) & 0.39 & 0.63 & 0.36 & 0.91 & 1.08 & 1.56 & 1.66 \\
Net Interest margin (\%) & 1.93 & 2.06 & 1.95 & 1.98 & 1.82 & - & - \\
Classified loans to gross loans (\%) & 15.9 & 10.6 & 11.5 & 8.0 & 5.78 & 2.95 & 1.28 \\
Cost to income ratio (\%) & 32.5 & 27.7 & 30.8 & 33.3 & 32.8 & 34.7 & 32.0 \\
Adjusted earnings per share (HK\$) & 0.29 & 0.48 & 0.26 & 0.63 & 0.75 & 1.13 & 1.28 \\
Capital adequacy ratio ${ }^{\mathrm{b}}$ (\%) & - & - & 14.4 & 14.0 & 15.1 & 16.1 & 15.4 \\
Average Liquidity Ratio ${ }^{\mathrm{c}}$ (\%) & - & - & 39.9 & 41.2 & 37.8 & 36.0 & 42.0 \\
Employees (person) & 15,401 & 14,480 & 13,428 & 13,191 & 13,188 & - & - \\
Profit per employee (HK\$ 1,000) & 245 & 440 & 278 & 612 & 659 & - & - \\
\hline
\end{tabular}

Note: ${ }^{a}$ Return on average total assets is calculated by dividing the profit after taxation with the daily average balance of total assets for the year. ${ }^{\mathrm{b}}$ As the Hong Kong branches of the Transferring Banks (excluding Hua Chiao) were not required to maintain a minimum capital adequacy ratio prior to the Restructuring and Merger, a comparison of the capital adequacy ratio for 1999 and 2000 is not meaningful and accordingly is not presented. ${ }^{c}$ Prior to the Restructuring and Merger, the liquidity ratio of each of the Transferring Banks was managed on an individual basis. As a result, the average liquidity ratios of BOCHK for the periods prior to the Restructuring and Merger are not comparable and accordingly are not presented.

Source: BOCHK Global Offering Prospectus, BOCHK Annual Reports 2002-2005.

Table 6: Comparative Performance of Banks in Hong Kong \& Mainland China

\begin{tabular}{|c|c|c|c|c|c|c|c|}
\hline HK\$ mil. & $\mathrm{H} 107^{\mathrm{a}}$ & $\begin{array}{l}\text { HSBC } \\
\text { H106 }\end{array}$ & H105 & HI07 & $\begin{array}{c}\text { BOCHK } \\
\text { H106 }\end{array}$ & H105 & $\begin{array}{l}\text { China }^{\mathrm{b}} \\
\text { FY05 } \\
\end{array}$ \\
\hline Total Assets & $3,666,024$ & $2,897,825$ & 2,579,396 & $1,047,095$ & 850,206 & 813,333 & - \\
\hline $\begin{array}{l}\text { Net interest } \\
\text { margin (\%) }\end{array}$ & 2.36 & 2.18 & 2.15 & 2.03 & 1.81 & 1.58 & 2.5 \\
\hline $\begin{array}{l}\text { Costs/Income } \\
(\%)\end{array}$ & 34.1 & 39.4 & 38.4 & 28.3 & 28.2 & 32.5 & 43.5 \\
\hline $\begin{array}{l}\text { Net income/ } \\
\text { avg. assets (\%) }\end{array}$ & 2.00 & 1.50 & 1.57 & 1.55 & 1.73 & 1.63 & 0.55 \\
\hline $\begin{array}{l}\text { Tier } 1 \text { capital } \\
\text { ratio }\end{array}$ & 8.3 & 12.1 & 11.4 & 13.6 & 14.2 & 14.8 & 6.4 \\
\hline $\begin{array}{l}\text { Capital/ } \\
\text { Weighted Risks }\end{array}$ & 11.2 & 13.1 & 12.2 & 14.3 & 14.6 & 15.7 & 8.2 \\
\hline
\end{tabular}

Notes: ${ }^{\text {a }}$ H107 represents first-half 2007 financial results, H106 first-half 2006 and H105 first Half 2005.

${ }^{\mathrm{b}}$ Average of 14 Chinese commercial banks for the financial year 2005. Aggregate performance ratios exclude ICBC. Asset quality figures exclude Bank of Beijing and Agricultural Bank of China.

Source: Fitch $(2006,2007)$ 